Kamila Sobieraj*

\title{
Current problems of evaluation concerning the impact of energy investments upon the environment
}

http://dx.doi.org/10.12775/PYEL.2012.003

\section{Introduction}

Enormous investment needs regarding the energy sector are related to the necessity of assuring energy security to citizens. They also enforce taking up multidimensional activities. The investment process regarding energy undertakings shows special characteristics if we compare it to undertakings in other sectors of economy. These are above all strategic investments, whose taking up and carrying out determines the economic growth (especially in the times of economic recession) and assures proper functioning of social and economic life in the state. A characteristic feature of this process is its multi-stage character, complexity of procedures, considerable distribution

" PhD in Law, Associate Professor, The Chair of Environment Management Law, Law Faculty, Canon and Administration Law, The John Paul II Catholic University of Lublin. 


\section{Kamila Sobieraj}

in time and space (it often includes numerous, so called accompanying investments as well), and accordingly the need to incur high financial outlays. Conducting economic activity regarding energy also generates environmental problems, irrespective of the technology and source of energy, although the intensity of impact clearly depends on those factors. Transformation of global and regional economy towards low-emission economy forces to gradually resign from high $\mathrm{CO}_{2}$ emission energy sources towards those low emission ones, as well as to use installations reducing emissions levels, which is (and will be) a regularly deepening process. It makes it a current duty of the state to assure functioning of low emission energy investments, often based on innovative technological solutions (technological innovativeness of energy investments), being a real step towards the sustainable development.

Specific character of energy investments determines the course and nature of an investment process. An indispensable part thereof in the energy sector is also the multiple environmental impact assessment (further referred to as EIA) (also in relation to the undertaking itself) aimed at defusing conflicts between the need for energy investments' intensification and environmental protection, including Natura 2000 areas. Carrying out a strategic assessment of the impact upon the environment requires resolving among others plans and programmes in the energy industry. An investor's application for implementing an energy undertaking must be often preceded by the change in the study of conditions and directions of a local (gmina) spatial development plan, as well as spatial development plans, within which the EIA is performed ${ }^{1}$. It must be emphasized that an element of each strategic EIA is always an assessment of the impact of a plan or programme upon Natura 2000 areas, which is subject to all requirements concerning a strategic EIA ${ }^{2}$. The project of the above planning documents may not be accepted if the strategic EIA implies that such a project might impact negatively a Natura 2000 area. According to the provisions of the regulation of the Council of Ministers of 9 November 2010, energy

1 See article 46 and 47 of the Act of 3 October 2008 on Sharing Information on Environment and its Protection, Participation of the Society in Environmental Protection and Environmental Impact Assessment, Journal of Laws of 2008, No 199, item 1227, further referred to as the Act on Sharing Information.

2 See. M. Bar, J. Jendrośka, Ocena oddziatywania przedsięwzięcia na środowisko a ocena oddziatywania na obszar Natura 2000, [in:] B. Rakoczy, M. Pchałek (ed.), Wybrane problemy prawa ochrony środowiska, Warszawa 2010, p. 17. 
investments have been included among the undertakings which may always affect the environment considerably ${ }^{3}$. In the case of undertakings that might significantly affect the environment, there is always an environment impact assessment carried out. Within EIA, the issue of impact upon Natura 2000 areas is always considered ${ }^{4}$. In case of undertakings considerably affecting the environment, an appropriate authority following the procedure of individual selection decides as regards the obligation of conducting EIA. If it is proven in the course of the undertaken procedure that intended actions may, separately or jointly with other actions, have a considerable negative impact upon the objectives of Natura 2000 area conservation, then their implementation will not be possible ${ }^{5}$. Considering in particular the multi-stage character, complexity, as well as technological innovativeness of most energy investments, it is worth emphasizing that an individual EIA may be carried out many times (with reference to the same undertaking).

High diversity of Polish natural habitat is expressed among others in a considerably wide area covered by Natura 2000 network. It is assumed that in Poland, on the grounds of the EU directives, about $20 \%$ of the country's surface is subject to protection by way of the areas being the habitat of wild fauna and flora, as well as natural habitats of European significance subject to conservation ${ }^{6}$. The European standards referring to Natura 2000 sanctuaries have been transposed mainly to the provisions of the Act of 16 April 2004 on Wildlife Conservation ${ }^{7}$. A general ban concerning undertakings that might have a negative impact upon a Natura 2000 area, refers not only to the ones located in those areas or in their immediate vicinity, but also to undertakings located in the areas far from wildlife conservation, as the very impact of an activity upon the area is sufficient ${ }^{8}$.

3 See $\$ 2$ section 1 points 3 i 6 of the regulation of the Council of Ministers concerning undertakings that may considerably affect the environment, Jouranl of Laws of 2010, No 213 item 1397.

4 See M. Bar, J. Jendrośka, Ocena oddziatywania przedsięwzięć, p. 21 and 22.

5 Article 33 of the Act of 16 April 2004 on Environmental Protection, Journal of Laws of 2009 , No 151, item 1220.

6 M. Górski (ed.), Interwencje ekologiczne w obronie ostoi Natura 2000. Praktyczny poradnik, Marki 2010, p. 6.

7 Act of 16 April 2004 on Natural Habitats Conservation, unified text, Journal of Laws of 2009 , No 151, item 1220 with amendments.

8 Z. Brodecki (ed.), Ochrona przyrody przed Europejskim Trybunatem Sprawiedliwości. Komentarz, Marki 2010, p.102. 


\section{Kamila Sobieraj}

To determine an investment impact upon the environment is not to reduce it to the statement that the investment covers a part of a Natura 2000 area, as a distant undertaking may also exert a negative influence upon the areas subject to conservation. Negative impact appearance is not necessary either, the very risk of its appearance suffices. It is especially important in case of accomplishment of such energy investments as nuclear power plants and their accompanying investments (potentially high risk of negative impact upon very distant areas). It must be also indicated that a vast part of areas where shale gas may be found overlaps with Natura 2000 areas subject to conservation, wildlife sanctuaries, protected landscape areas or national parks. Insufficient from the point of view of a potential impact of the whole investment upon Natura 2000 area (and all the more so upon the integrity among those areas and their natural links with other conservation areas) - the investment consisting in searching, identification and excavation of shale gas - is restricting the assessment to the area of drilling works, as the impact is also related to creating a warehouse support facilities or increased transportation. What is more, following the rule of caution, subject to conservation is each area of Natura 2000 network areas, both the one officially designated so far, irrespective of its having been assigned protective tasks schedule or not, as well as potential and planned Natura 2000 areas, interpreted as the areas that meet classification criteria, included in so called bird conservation directive and natural habitat conservation directive, but not formally designated as bird conservation areas or natural habitat conservation areas, and moreover the areas that have been included in the so called Shadow List (have only been indicated to be included by non-governmental organizations), but they are not on the national list submitted to the Commission?.

To sum up, an EIA procedure, including the often carried out within EIA so called nature procedure (repeated several times with reference to the same undertaking) constitutes an important part of investment process regarding energy sector and significantly influences its course.

9 See the judgement of ECJ in case C-96/98, The Committee v France - Poitevin Marshes and ECJ ruling in case C-388/05, The Committee $v$ the Italians - Valloni e steppe pedegarganiche and the ruling of the Supreme Administrative Court in Warsaw of 13 March 2009, files ref. No IV Sa/Wa 84/09 and the ruling of the Supreme Adm. Court in Gdańsk of 10 December 2008, Ref. No of files II SA/Gd 370/08. 
In the Polish legal system, special laws are more and more often treated as a convenient instrument for a fast and efficient execution of public aim investments, including energy investments. Energy investments are viewed as cure-all for investment processes, such as lengthiness or complexity of administrative procedures, which are especially troublesome in the case of capital-consuming investments, spread in time and space and always affecting the environment, such as those planned and carried out in the energy sector. It is increasingly noticeable, however, that the means that enable speeding up investment procedures are included in special laws, unfortunately sometimes at the expense of environmental protection requirements (including in particular decisions modifying EIA ${ }^{10}$. The drafter seems to overlook the fact that wildlife conservation is the value guarded not only by the Constitution ${ }^{11}$, but also protected by EU standards, whose observance is monitored by the EU bodies (Natura 2000 areas are subject to special surveillance). The regulations aimed at acceleration and increasing the efficiency of investment processes by reducing the requirements of wildlife conservation may be found in the special Act of 29 June 2011 on preparing and completion of nuclear energy facilities and accompanying investments ${ }^{12}$, as well as in the draft of special Act of 6 June 2012 on distribution channels ${ }^{13}$.

Exclusive orientation of the legislator into implementing measures accelerating an investment process while overlooking the need to account for its specificity, may bring effects entirely different from the intended ones. Excessive concern for the rate of legislation procedures, often at the expense of wildlife conservation requirements in case of special laws on the energy industry may result in long-term consequences. It may be above all a prolonged period, or even blocking (in the case of incorrect usage of premises, allowing to take up actions that may have a considerably negative impact upon conservation requirements of a Natura 2000 area)

10 In the doctrine it is often emphasized that the measures introduced in special laws aimed at acceleration of the investment procedure result in infringement of ownership rights. See. Legal Expertise by the Human Rights Fund on the draft of so called flood control special law, prepared under the guidance of A. Bodnar, Warsaw 2009, http://www.hfhrpol. waw.pl/pliki/Opinia_specustawa_powodziowa_www.pdf [date of entry: 30 June 2012].

11 See. article 74 of the Constitution of the Republic of Poland of 2 April 1997, Journal of Laws of 1997, No 78, item 483 with amendments.

12 Journal of Laws of 2011, No 135, item 789.

13 Draft of the Act of 6 June 2012 on distribution channels, version No 4.9. 


\section{Kamila Sobieraj}

an investment process, whose completion is indispensable for inspiring the economic growth or proper functioning of social and economic life of a state. Non-observance of the EU law (incomplete or improper implementation thereof), too 'liberal' approach to premises allowing to undertake actions that might negatively impact Natura 2000 conservation objectives, may also result in the investor being refused the EU funds, as the observance of law is the prerequisite for applying for the EU funds. It is of special importance in view of the fact that completion of energy undertaking projects (especially those innovative ones) is nowadays most often supported by the EU funds.

\section{Special Law on Preparing and Implementation of an Investment Regarding Nuclear Energy Facilities and Accompanying Investments}

According to the intention of the drafter of the special law on Preparing and Implementation of an Investment Regarding Nuclear Energy Facilities (...) inclusion in a separate act of law of the regulations devoted exclusively to preparing and implementation of nuclear energy objects and accompanying investments 'shall allow to reduce major investments risks, and thereby shall increase a chance to prepare and implement such investments and accomplish them in an efficient and effective way ${ }^{14}$. It must be emphasized however, that the special law does not regulate all the issues connected with preparing and accomplishment of those investments. It only excludes the regulations concerning spatial planning and development, and introduces as a rule lex specialis into several other laws, among others into the Act of 3 October 2008 on the release of information about the environment and its protection, participation of the public in environmental protection and assessment of the environmental impact ${ }^{15}$, regarding the regulations on environmental impact assessment (EIA).

EIA must be carried out even before the formal commencement of the investment process as regards nuclear energy facilities and the

14 Assumptions of the draft for preparing and implementation of investments regarding nuclear energy facilities and the accompanying investments, Warsaw, January 2011, p. 12.

15 Journal of Laws of 2008, No 199, item 1227. 
accompanying investments, which shall be equivalent to issuing a decision on establishing the location of a nuclear power facility investment ${ }^{16}$. The obligation to acquire a decision on environmental conditioning before obtaining a decision to establish the location of nuclear energy facility must be considered as meeting the condition for carrying out an EIA before obtaining a 'development consent', which conforms to the Directive 85/337/ $\mathrm{EEC}^{17}$ and follows rich judicature of the UE Court of Justice ${ }^{18}$. At the same time, however, at that stage, technological details concerning the construction technology or nuclear power plant working may not be known. Actual usefulness of such EIA results may thus seem doubtful. According to the present legal status, another EIA procedure is scheduled however not earlier than at the stage of building permit procedures pending ${ }^{19}$. This is caused by the legislator's resignation from the obligation to carry out the next EIA procedure and to issue the next decision on environmental conditioning related to issuing a building permit for a nuclear energy facility (as a decision related to exposure) referred by the investor to the Chairman of the National Atomic Energy Agency on the grounds of article $39 \mathrm{k}$ of the Atomic Law Act ${ }^{20}$. Resignation from the duty of carrying out the next EIA procedure at the stage of acquiring the fundamental decision certainly aims at accelerating and streamlining the whole investment procedure. On the other hand, it may prevent the investor from efficient planning of the investment process in the energy sector and from proper consideration of environmental protection requirements, and may generate additional costs. Modifications of the project and possible presentation of alternative variants at the stage of issuing a building permit may seem very difficult in practice (or just impossible). It would be necessary then to postulate de lege ferenda an introduction of mandatory EIA at the stage

16 See article 72 section 1 point $18 \mathrm{a}$ of the Act on sharing information.

17 Council Directive No 85/337/EEC of 27 June 1985 concerning assessment of impact of some public and private undertakings upon the natural habitats, OJ L $175 \mathrm{dd} 05.07 .1985 \mathrm{r}$., p. 40-48.

18 Z. Bukowski, Ponowna ocena oddziatywania na środowisko w polskim prawie, [in:] Wybrane problemy prawa ochrony środowiska, B. Rakoczy, M. Pchałek (ed.), Warsaw 2010, p. 38 and the EU CJ judicature cited there.

19 See. article 82 section 1 point $4 \mathrm{a}$ of the Act on sharing information

20 See article 62 point 10a) of the law on preOparing and implementation of investments regarding nuclear energy facilities (...). Act of 29 November 2000 - Atomic Law, unified text. Journal of Laws of 2012, item 264. 


\section{Kamila Sobieraj}

of acquiring a fundamental decision, among others to enable the investor efficient planning of the investment process course in the energy sector (following the assumption that analysis of alternative solutions should take place as early as possible at the stage of planning the project).

The expansion of low emission nuclear energy arouses social conflicts, which may result from antagonistic interests of different subjects that the investments concern, from hostility or differences in systems of values by which the opposite parties are guided. Properly carried out social participation takes special meaning in the case of such investments. For this reason taking the final decision of a nuclear power plant investment location must be preceded by a social campaign, carried out in order to inform the society honestly of the disadvantages and advantages of nuclear energy, and the decision procedures - nationalized according to the EU and international $\mathrm{law}^{21}$. In the special law concerned there are however regulations that may contribute to creating even more conflict generating atmosphere around this type of investments. According to article 20 section 2 , the parties in the proceedings may only be such ecological organizations that have been entered in an appropriate register not earlier than one year before instituting proceedings aimed at issuing a decision on environmental conditioning for a nuclear facility. It may be just assumed that the purpose of introducing a separate regulation is not making the decision process concerning 'a conflict generating nature' of this investment deeper in social terms, but to restrict it. Introducing a premise of one-year existence for an ecological organization and limiting its right of participation in the proceedings exclusively to the registered ecological organisations may be considered to be a violation of the provisions of article 6 of the Directive $85 / 337 / \mathrm{EEC}$, it will also cause the opposition and protests of ecological organizations, which may in turn lead to lengthening the whole procedure and even block accomplishment of the investment.

In order to assure the highest level of professional knowledge, The Director General for Environmental Protection has been appointed with appropriate authority to issue decisions on environmental conditions for nuclear energy investments ${ }^{22}$. As it is suggested by S. Urban, introducing

21 A. Hatadyj, K. Sobieraj, Ocena oddziatywania na środowisko przedsięwzięć z zakresu energetyki jadrowej. Wybrane problemy, [in:] M. Górski (ed.), Prawo ochrony przyrody a wolność gospodarcza, Łódź-Poznań 2011, p. 185.

22 See article 75 section 1 point $1 \mathrm{a}$ of the Act on sharing information 
this difference in contrast to standard solutions, may raise (in the context of other laws sharing environmental information) questions about other entities that take part in the implementation of the planned undertaking give an opinion on the undertaking ${ }^{23}$. Imprecisions, insufficient regulations of legal standards may cause the need for administrative bodies to act in the conditions of high uncertainty as to the correctness of the applied law and that increases the risk of the higher rate of appeals in the instance courts and filing complaints to the administrative court, which as a consequence will lengthen the investment process.

\section{Draft of Special Law on Distribution Channels}

Similarly, the intention of the planned specialist law on distribution channels is 'facilitating and speeding up the process of acquiring appropriate decisions by investors enabling the construction of technical infrastructure, as well as its expansion and modernization, and also creating favourable conditions for preparing and implementation of further investments $(\ldots)$ ' in order to '( ...) assure energy security and securing fuel supplies ${ }^{24}$. A draft of the special law excludes only the regulations concerning spatial planning and development (article 28 section 1 of the draft), and as a rule introduces changes in the regulations in force, including the law on access to environmental information regarding EIA.

According to the regulations in force, gas pipelines and electric power grids are included among undertakings that may considerably influence the environment, thereby requiring appropriate assessment and decision concerning environmental conditioning ${ }^{25}$. High diversity of Polish natural habitats, expressed among others in a considerably wide area covered by Natura 2000 network, wherein on the grounds of EU directives the wild fauna and flora, as well as natural habitats of European significance are

23 S. Urban, Obiekty energetyki jadrowej, Law and environment' 2012, No 1(69), p. 92.

24 See the justification for the draft of law [date of entry: 30.06.2012], p. 2.

25 Regulation of the Council of Ministers of 9 November 2010 concerning undertakings that may have a considerable impact upon the environment, Journal of Laws of 2010, No 213 item 1397. 


\section{Kamila Sobieraj}

subject to conservation ${ }^{26}$, makes it actually impossible for such undertakings to be located far from the areas included in Natura 2000 network or directly pass through such areas, which is related to the obligation of carrying out so called nature assessment.

The drafter has predicted that the decision concerning environmental conditioning should precede issuing a decision on establishing a distribution channel and a decision to locate the next appliance in the distribution channel ${ }^{27}$. The EIA must be carried out before the formal commencement of investment process within planning and accomplishment of new distribution channels. The application for issuing a decision to establish distribution channels shall be accompanied by a decision on environmental conditioning $^{28}$. In the draft there is no reference to article 88 section 1 of the Act on access to information, concerning a chance to carry out the next EIA in such a way as to enable carrying out such an assessment also in the course of proceedings aimed at establishing a distribution channel.

The European Union law requires that in case of two-stage system of issuing permits, a possibility of carrying out an EIA at both the stages must exist ${ }^{29}$. In case of investments aimed at planning and accomplishment of distribution channels, we may face a two-stage system of issuing investment permits: initially, an urban planning decision (on establishing a distribution channel), and then a decision concerning construction (building permit for a distribution facility). The draft concerned provides in this respect for a different (if an entrepreneur applies for it), alternative approach model. The drafter shall empower a proper authority to grant (whereby the authority 'grants' and not 'may grant') the decision to establish a distribution channel, a permit to build a distribution facility and confirm a building project ${ }^{30}$. It seems that in that case, at the absence of separate proceedings to issue a building permit, the possibility of carrying out the next EIA seems excluded, too. The whole investment process shall thus be based on EIA and establishments made within the decision on environmental conditioning issued before a formal commencement of this process (even

\footnotetext{
M. Górski (ed.), Interwencje ekologiczne, p. 6.

See article 77 point 4 of the draft.

See article 14 section 2 point 10 of the draft.

29 Z. Bukowski, Ponowna ocena, and th cited judicature of the EU Court of Justice.
} $37-38$

30 See article 39 of the draft. 
much earlier). Excluding a possibility of re-assessment may be considered a violation of EU standards with respect to environmental protection (in cases where there was no possibility of defining all important natural habitat's aspects or of acquiring information on accumulated undertakings during the basic EIA).

A general ban to undertake actions that may separately or if combined with other actions have a considerable negative impact upon the protection objectives of Natura 2000, including especially the deterioration of natural habitats, as well as flora and fauna habitats, and moreover actions that might have a negative impact upon the species for which Natura 2000 area was designated, or to deteriorate integrity of Natura 2000 area or its associations with other areas has no strict character ${ }^{31}$. The appropriate public administration authority may issue a permit for accomplishment of a plan or undertaking that may have a negative impact upon a Natura 2000 area if the premises formulated in article 34 of wildlife conservation act are met. It shall take place when: 1) no alternative solutions exist allowing to accomplish an undertaking so as to avoid its negative influence upon the environment; 2) a superior social or economic alternative social interest will be indicated weighing in favour of the undertaking accomplishment, whereby - in case of areas at which priority species or sanctuaries appear: a) premises allowing to grant a permit for an undertaking accomplishment, are limited to those listed in article 34 section 2 of the Act on wildlife conservation, i.e. the concerns of: wildlife and people's existence protection, assuring common security, acquiring positive consequences of major significance for the natural habitat; $b$ ) in view of other than the above types of social or economic interest, provided that the opinion of the European Union is obtained; 3) assuring compensating measures necessary to assure general coherence of Natura 2000 areas. The special nature of energy investments shall cause many more difficulties in applying premises allowing to accomplish the undertakings that may considerably affect Natura 2000 areas, if we compare it with other undertakings in other sectors of the economy.

Above all, it must be emphasized that the afore-said premises allowing to take up actions that may have a considerable negative effect on the protection objectives of Natura 2000 shall apply exclusively to the already designated areas of Natura 2000. Whereas, as indicated at the beginning,

31 See article 33 section 1 of the Act on natural habitats conservation. 


\section{Kamila Sobieraj}

each area is subject to legal protection, as well as potential and planned Natura 2000 areas, but formally not included in Natura 2000 network or in the areas included in the so called Shadow List, but not included in the national list addressed to the Council. In these areas, a stricter conservation regime applies in view of the impossibility to refer to the afore-said premises. The EU Court of Justice finds unacceptable for a member state to draw profits by way of not meeting the obligations following the EU regulations ${ }^{32}$. On the other hand, the practice applied makes it impossible for an investor to efficiently plan the course of investment in the energy sector, especially all types of infrastructural line investments (including power grids, etc.) or e.g. investments related to searching, recognition and excavation of shale gas. Therefore, closing the list of Natura 2000 areas network as soon as possible must be postulated.

The need for new energy investments is within the limits of the idea of diversification, which is the means to energy security. It is also beyond doubt that assuring energy security is within public interest. The energy sector belongs undoubtedly to strategic areas as regards the economy and EU Member States policy. Functioning of the energy sector is especially closely related to the public interest category. Therefore, the Polish legislator names them public aim investments more often and introduces regulations aimed at accelerating and streamlining this type of investment processes. Public aim investments are those regulated by the Act of 29 June 2011 on preparing and accomplishment of nuclear energy facilities and the accompanying investments ${ }^{33}$, as well as in the draft of the Act of 6 June 2012 on distribution channel $^{34}$, the draft of the act on renewable sources of energy ${ }^{35}$, as well as construction and maintenance of $\mathrm{CO}_{2}$ transmission cables and facilities shall be considered the public aim on the grounds of the regulations of geological and mining law. Similarly, the status of investments related to searching, identification and excavation of shale gas in the future law on excavation of hydrocarbons, their taxation and Hydrocarbon Fund shall be regulated.

\footnotetext{
32 Such a requirement may be inferred from ECJ ruling in cases C-244/05 Bund Naturschutz in Bayern in relation to the ruling in case C-355/90 Santon a Marshes as well as C-371/98 First Corporate Shipping; Z. Brodecki (ed.), Ochrona przyrody, p. 51, 59-61, 182-186,.

33 Journal of Laws of 2011, No 135, item 789.

34 Draft of the Act of 6 June 2012 on distribution channels, version No 4.9.

35 Draft of the Act of 9 October 2012, version 2.0.2.
} 
Not each type of public interest may be considered paramount with reference to special value of protected interests ${ }^{36}$. The notion of paramount public interest has been defined neither in the natural habitats conservation law nor in the so called natural habitats directive. However, in the provisions of article 34 section 2 points $1-3$ of the natural habitats conservation act human health, public security and beneficial effects of fundamental meaning to the environment have been listed as examples of necessary requirements for the paramount public interest. Of course the notion of the necessary requirements of the paramount public interest also includes other requirements than indicated in the examples types of social or economic concern $^{37}$.

It's also worth referring to the presented in doctrine analysis of the idea of citizens security (including public security as well). Following the provisions of article 5 of the Constitution of the Republic of Poland, defining the fundamental directions and aims of the State, environmental protection, as well as citizens security, have been regarded as one of the fundamental tasks (functions) of public authorities, which should be carried out according to the sustainable development rule. Although the meaning of citizens security has not been explained in the Constitution of the Republic of Poland precisely, it is assumed that it should be widely understood, not only in view of the military threats. Provisions of the Constitution of the Republic of Poland provide that the task of the state is assuring security in several spheres of public activity ${ }^{38}$. The notion of citizens security also includes energy security. Bearing in mind regularly growing energy demand caused by technological expansion and the global economic growth, assuring energy security determines the growth of economies (production processes and performing services depend on energy supplies), and also assures peaceful existence to the individuals and communities, by which it contributes to the social order.

However, it is worth pointing out that the provisions of article 75 of the act on transportation channels introduce changes in the law on distribution

36 Z. Brodecki (ed.), Ochrona przyrody, p. 171.

37 A. Haładyj, Nadrzędny interes publiczny jako warunek realizacji, [in:] J. CiechanowiczMc-Lean, T. Bojar-Fijałkowski (ed.), Prawo ochrony środowiska jako warunek prowadzenia dziatalności gospodarczej, Gdańsk 2009, p 40.

38 W.J. Wołpiuk, Bezpieczeństwo państwa i pojęcia pokrewne. Aspekty konstytucyjnoprawne, [in:] W. Sokolewicz (red.), Krytyka prawa. Niezależne studia nad prawem. Tom II Bezpieczeństwo, Warsaw 2010, p. 181 and others. 


\section{Kamila Sobieraj}

channels, consisting in adding among others article 4b following article $4 \mathrm{a}$, according to which whenever the law on nature conservation makes a reference to general security, also energy security is meant according to the Act of 10 April 1997 - Energy law. The added regulation aims at clarification that energy security is one of the common types of security. Bearing in mind that it is not possible for linear undertakings concerning infrastructural investments (including power grids) not to be located near Natura 2000 wildlife conservation areas or pass immediately through such areas, the draft of the act on distribution channels also provides for the new content of article 34 section 1 of the act on natural habitat conservation. If the necessary requirements of the public interest are in favour, including the social or economic requirements, at the absence of alternative solutions, the appropriate regional manager, and in marine areas - manager of the appropriate marine office, may give permission for implementation of a plan or actions that may exert a considerably negative influence upon the aims of Natura 2000 areas or the areas included in the list referred to article 27 section 3 point 1, especially with respect to construction and maintenance of the infrastructure assuring energy security, providing wildlife compensation necessary for coherence and proper functioning of Natura 2000 areas network. According to the planned changes, especially the investments regarding infrastructure assuring energy safety may be subject to a permit referred to in article 34 section 1 of the act on natural habitats conservation.

It should be assumed then that energy security is within the superior public interest, referred to in the regulations of natural habitat directive and wildlife conservation. The conflict between assuring energy security by investing in the energy objects and installations, and the values of natural habitats resources seems to be settled in favour of assuring energy security. On the other hand, however, it must be remembered that the notion of 'securing energy safety' means assuring continuous energy supplies at optimum costs, maintaining the environmental protection requirements ${ }^{39}$. The environmental protection is thus an immanent element of the notion. Moreover, a possibility to refer to the premise of 'paramount public interest' with regard to a particular energy undertaking exists however only in case of proving simultaneously the lack of alternative varieties for an undertaking,

39 Notion of energy security, see.: article. 3 point 16 of the Act of 10 April 1997. Energy law, Journal of Laws of 2006; No 89, item 625 and Energy Policy of Poland until 2030 adopted by the Council of Ministers on 10.11.2009, M.P. of 2010 No 2, item 11. 
as well as establishing compensatory measures in such a way as they may provide maintenance or strengthening the total coherence of Natura 2000 areas, be relevant to a particular area or an existing damage and be $v_{i a b l e}{ }^{40}$. Revealing these two premises in the case of energy investments may, on the other hand, be related to special difficulties, bearing in mind mainly their multi-stage nature, complexity, as well as technological innovativeness and the need for special location conditioning (e.g. access to primary raw materials, requirements for investment area regarding surface conditions, as well as infrastructure and environment). Laconically worded premises for 'alternative solutions' and 'compensatory measures' grants the appropriate authorities obliged to interpret and apply them a significant scope of discretionary space. Appropriate interpretation and application of those premises is the matter of fundamental importance for the investor interested in obtaining a licence to implement an energy investment. It requires however an especially urgent knowledge acquisition and opinion analysis ${ }^{41}$ regarding the Committee guidelines and legislation of the EU Court of Justice as well as the national administration courts with regard to a particular undertaking, both by appropriate public administration authorities and investor. Vagueness of premises allowing to undertake actions that may have a considerably negative impact upon the aims of Natura 2000 areas conservation, as well as lack of regular, elaborated application principles by appropriate authority.

\section{Summary}

Enormous investment needs within energy sector result from the need to assure energy security to citizens. The demand for new energy investment

\footnotetext{
40 Z. Brodecki (ed.), Ochrona przyrody, p. 172.

41 Diversification and profound analysis of the Committee opinions issued according to article 6 sections 3 i 4 of natural habitats conservation by S. Urban, Opinie Komisji Europejskiej w sprawie planów i przedsięwzięć negatywnie oddziatujących na obszary Natura 2000; „Problems regarding environmental assessments” 2006, No 1; there: Negatywne oddziatywanie planów iprzedsięwzięćna sieć Natura 2000 a nadrzędny interes publiczny. Analiza pojęcia "powody o charakterze zasadniczym wynikajace z nadrzędnego interesu publicznego", [in:] J. Jendrośka, M. Bar, Wspólnotowe prawo ochrony środowiska i jego implementacja w Polsce trzy lata po akcesji, Wrocław 2008, p. 149-166.
} 


\section{Kamila Sobieraj}

ranges within the need for diversification, which is the means to provide energy security. It also unquestionable that assuring energy security is within the public interest. In order to meet the requirements, special acts allow considerable simplification and acceleration of energy investments implementation, which deserves recognition. Introducing instruments aimed at streamlining and acceleration of investment processes in order to provide energy security and security as regards fuels supplies, they emphasize public interest calls for immediate elimination of existing barriers.

However, there are controversies if we consider the fact that the measures aimed at accelerating investment procedures are introduced into special laws (or existing barriers are eliminated) at the expense of natural habitats conservation requirements. Taking up such actions may be the proof of entire lack of understanding for the very notion of 'providing energy security', which is based on assuring regular supplies of energy at optimum expenses, maintaining environmental protection requirements. Environmental protection is an integral element of the notion.

Energy investments always generate environmental problems. Special care of the EU whether the limitations imposed by the European law effectively disable appearance of a threat to the environment, results in a dynamic growth of the number of EU standards regarding environmental protection, covering by their scope an increasingly extensive areas of energy sector issues, which then must be implemented into national legal structures. Introduced as special laws (among others the law on sharing information) lex specialis seem however to simplify and reduce the number of environmental impact assessment proceedings, as well as restrict the access of ecological organisations to the proceedings regarding impact of those investments upon environmental protection in a way that might breach EU natural habitats conservation regulations. It is controversial event to introduce regulations which provide the grounds for statement that EU nature conservation standards 'may be' violated. Such entries, unfortunately, increase the risk of appeals in the instance courts as well as filing complaints to administrative court, or social protests, which as a result shall lead to lengthening an investment process, as well as create the risk of the Council intervention. 